DOI https://doi.org/10.18551/rjoas.2020-11.29

\title{
VILLAGE OWNED ENTERPRISES (BUMDES) PERFORMANCE: A CUSTOMER SATISFACTION APPROACH TO THE TOURISM MANAGEMENT
}

\author{
Meitasari Deny, Pertiwi Vi'in Ayu*, Pratiwi Destyana Ellingga \\ Department of Socio-Economics, Faculty of Agriculture, University of Brawijaya, \\ Malang, Indonesia \\ *E-mail: viinayu@ub.ac.id
}

\begin{abstract}
Customer satisfaction is the comparison between the performance expected by the customer and the actual performance in the field. When the actual performance is higher than the customer's expectations, the customer feels satisfied and vice versa. Measuring customer satisfaction is useful for capturing information about what customers need and also for maintaining customer loyalty to the products or services being sold. This study aims to identify the attributes that visitors consider when visiting tourist objects and to analyze the overall level of customer satisfaction by looking at the level of expectations of these attributes. This research was conducted at Boonpring Andeman Malang Tourism Village in July - October 2020. The research approach used is quantitative with data analysis methods, namely the Importance Performance Analysis (IPA) diagram and the Consumer Satisfaction Index (CSI). The results showed that the attributes considered important and had a good performance by visitors were scenery, footpaths, fresh air, access to the driveway and parking area, the physical condition of toilets, cleanliness of the worship place, and clean water installations, while important attributes that require immediate handling for improved performance is a game vehicle; physical condition and cleanliness of shelters/cottages, amusement rides, information center; as well as comfort when taking selfies and enjoying games/rides. Based on the results of CSI calculations, it shows that the CSI value obtained is $75.21 \%$, which means that visitors are satisfied with the services provided by Boonpring Tourism Village Andeman Malang.
\end{abstract}

\section{KEY WORDS}

IPA, CSI, BUMDES, strategy, tourism.

The tourism sector is a sector that has the potential to be developed as a source of regional income. Law Number 10 of 2009 concerning Tourism states that the implementation of tourism is aimed at increasing national income in the context of increasing the welfare and prosperity of the people, expanding and equalizing business opportunities and employment opportunities, encouraging regional development, introducing and utilizing tourist objects and attractions in Indonesia as well as foster a sense of love for the country and strengthen the friendship between nations. Tourism activities can create demand, both consumption, and investment, which in turn will lead to the production of goods and services (BPS, 2019).

In the smallest government unit, the development of the tourism sector can be seen at the village government scale. There are many natural-based tourism potentials in the village area. Villages with good tourism potential can be a driving force for the rural economy considering that rural economic growth tends to be slower than the rate of economic growth in urban areas. Therefore, based on Law Number 6 of 2014 concerning Villages, this provides wide opportunities for villages to manage their existing potential. One of the ways to manage this potential is through the formation of BUMDes with business units that are managed as resources according to the potential of each village.

There are 251 tourism-based business units out of 7,890 business units established by BUMDes in East Java Province (DPMD Jatim, 2020). The tourism business unit established by BUMDes partly utilizes the natural potential of the local village as a tourist destination, such as mountain tourism, beach tourism, waterfall tourism, reservoirs, and so on. Apart from some tourism businesses that rely on artificial tourism, such as swimming pools, dams, and 
others. Currently, many tourism business units with the concept of a tourist village are chosen as a form of community support and village officials to improve the rural economy through developing village potential.

According to Hadiwijoyo in Syafi'i \& Suwandono (2015) tourism activities in the village are created from several things, they are good accessibility; having interesting objects in the form of nature, cultural arts, legends, local food that can be developed as tourist objects; support from the community and village officials; village security is guaranteed; available accommodation; adequate telecommunications and manpower; cool or cold climate; related to other tourism objects that are well known to the public.

One of the tourism-based BUMDes business units in East Java Province is the Andeman Boonpring Tour in Malang Regency. The Andeman Boonpring Tourism which is managed by BUMDes Kerto Raharjo is a mainstay business unit. Boonpring Andeman is a natural tourist attraction in the form of bamboo forests and artificial lakes from 9 springs. As BUMDes that are included in the advanced category, the tours offered by the manager of Boonpring Andeman Tourism are not only natural tourism but there are also children's and adult swimming pools equipped with water booms, people's markets, shops, and outbound (paddle boats, sailing boats, water balls. , ATVs, archery, horses, flying fox, playground, and trampoline). Besides, there is an educational tour in the form of a bamboo arboretum.

The number of visitors who come to Boonpring Andeman Tourism Village continues to increase. This means that this tourist village is starting to be known by the wider community. Therefore, to maintain visitor loyalty and capture information about what visitors need for the services offered by the manager of Boonpring Andeman Tourism Village, it is necessary to measure the level of visitor satisfaction. Given the increasing number of tourist-based business units managed by BUMDes, there will be competition. According to Sarjono (2013), the intense competition between similar businesses, both those that are just starting and those already known by visitors, requires tourism managers to see and take advantage of existing opportunities. In facing competition, business actors must be able to develop strategies to compete. An important strategy in business people because it is part of the activities designed to carry out business activities. The better and more precise the business strategy is implemented, the stronger it will be in facing competition and able to excel in business competition.

Based on this description, this study aims to identify the attributes considered by visitors when visiting tourist objects and to analyze the overall level of customer satisfaction by looking at the level of expectations of these attributes. From these findings, it is hoped that there will be improvements for the attributes that are still lacking by tourism management. Besides, this finding can serve as a reference for other BUMDes who want to set up similar businesses.

\section{METHODS OF RESEARCH}

One method of evaluating customer satisfaction and service quality in the field of outdoor tourism and recreation is the Importance-Performance Analysis (IPA). IPA is useful to help compare performance and satisfaction for management decisions, this analysis method can be used to examine two aspects of expectations in parallel: the importance and performance of certain attributes (Chen et al., 2010). The Importance Performance Analysis (IPA) method has the main function of displaying information about service factors which, according to consumers, greatly influence their satisfaction and loyalty and service factors that need to be improved because they are not yet satisfactory at current conditions. The IPA method combines the factors of importance and level of satisfaction in a two-dimensional graph, commonly known as a Cartesian diagram. Biesok \& Wyród-Wróbel (2015) Cartesian diagram in Figure 1. 


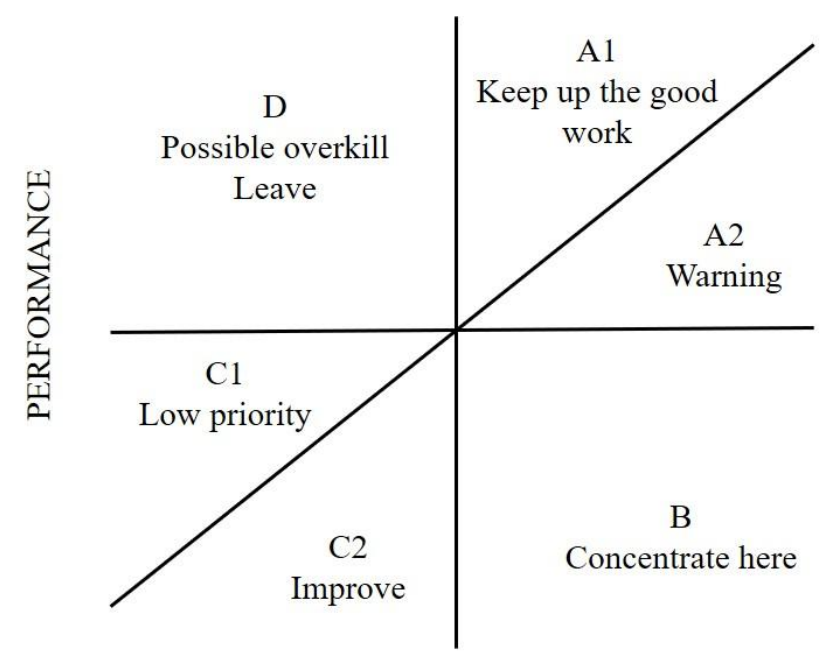

IMPORTANCE

Figure 1 - Biesok \& Wyród-Wróbel (2015) Cartesian diagram (Source: Biesok \& Wyród-Wróbel, 2015)

The quadrant contained in the Biesok \& Wyród-Wróbel (2015) Cartesian diagram is categorized into: Keep up the good work, the attributes in this quadrant indicate the opportunities that can be achieved or the main competitive ability of the product.

A2. Warning, is going well, but the attributes in this area need to be corrected as soon as possible because it can affect consumer satisfaction widely.

B1. Concentrate here, the attribute that is in this quadrant requires immediate handling to improve its performance and is the biggest weakness of the product.

C1. Low priority, attributes in this area are not prioritized to be fixed.

C2. Improve, the attributes in this area can be improved at a certain time.

D2. Possible over kill, the attribute in this quadrant indicates that the resources owned by the company are too allocated to these attributes and need to be distributed to help other attributes.

Furthermore, to analyze the overall level of customer satisfaction by looking at the level of expectations of product and service attributes, the Customer Satisfaction Index or CSI method is used. The analysis results obtained by the CSI method will explain how much the level of customer satisfaction with a product. How to calculate the amount of CSI according to Aritonang (2005) is as follows.

1. Determining the Mean Importance Score (MIS) and Mean Satisfaction Score (MSS), the values in the MIS and MSS are derived from the average importance level and performance of each attribute:

$$
\begin{aligned}
& \mathrm{MIS}=\sum_{i=t}^{n} Y i \\
& \mathrm{MSS}=\sum_{i=t}^{n} X i
\end{aligned}
$$

2. Weighting Factor (WF), is a function of the MIS or the average level of importance, each attribute expressed in percent of the total MISt for all tested attributes:

$$
\mathrm{WF}_{\mathrm{i}}=\frac{\text { MIS }_{i}}{\text { Total MIS }_{i}}
$$

3. Weighting Score (WS), is a function of MSS multiplied by Weighting Factor (WF). MSS or the average value of the level of the average value of the level of performance or the average value of the level of performance, satisfaction is obtained:

$$
W S=M S S \times W F
$$


Overall level of customer satisfaction is divided into five satisfaction criteria. The criteria can be seen in the table below (Ihsani, 2005).

Table 1 - CSI Value and Criteria

\begin{tabular}{ll}
\hline CSI Value & Criteria \\
\hline $0,81-1,00$ & Very satisfied \\
$0,66-0,80$ & Satisfied \\
$0,51-0,65$ & Quite satisfied \\
$0,35-0,50$ & Less satisfied \\
$0,00-0,34$ & Not satisfied \\
\hline
\end{tabular}

Source: Ihsani (2005).

Based on the criteria in table 1, each customer satisfaction criterion has a different range of values. Satisfaction criteria start from the highest, namely "very satisfied" which has a value range of 0.81 to 1.00 . Meanwhile, the lowest customer satisfaction criteria are "not satisfied" with a value range of 0.00 to 0.34 . The criteria obtained after conducting the analysis will be the basis for decisions in determining product development strategies to improve product performance to compete better.

\section{RESULTS AND DISCUSSION}

Visitors who are respondents in this study are visitors who are over 17 years of age. The number of respondents taken was as many as 31 people. The characteristics of respondents in Boonpring Andeman Malang Tourism Village can be seen in table 2. Most of the respondents' domicile came from outside Malang. Based on gender, there are more female respondents than male respondents. This is because women prefer nature tourism activities than men, while men make tourist visits on the wishes of their family and colleagues.

Table 2 - Characteristics of Respondents in Boonpring Andeman Malang Tourism Village

\begin{tabular}{|c|c|c|c|}
\hline Aspect & Answer Variations & Frequency & $\%$ \\
\hline \multirow[t]{2}{*}{ Domicile } & Malang Raya & 9 & 29,03 \\
\hline & Outside Malang & 22 & 70,97 \\
\hline \multirow[t]{2}{*}{ Gender } & Women & 25 & 80,65 \\
\hline & Male & 6 & 19,35 \\
\hline \multirow[t]{5}{*}{ last education } & Senior High School & 10 & 32,26 \\
\hline & Bachelor & 16 & 51,61 \\
\hline & Postgraduate & 1 & 3,23 \\
\hline & Junior High School & 1 & 3,23 \\
\hline & Elementary School & 3 & 9,68 \\
\hline \multirow[t]{6}{*}{ Profession } & Not yet working & 1 & 3,23 \\
\hline & Student & 10 & 32,26 \\
\hline & ASN & 3 & 9,68 \\
\hline & Private employees & 8 & 25,81 \\
\hline & Entrepreneur & 3 & 9,68 \\
\hline & Housewife & 6 & 19,35 \\
\hline \multirow[t]{5}{*}{ Income } & Rp. 0 - Rp. $1,000,000$ & 16 & 51,61 \\
\hline & Rp. $1,000,001$ - Rp. $2,000,000$ & 3 & 9,68 \\
\hline & Rp. $2,000,001$ - Rp. $3,000,000$ & 4 & 12,90 \\
\hline & Rp. $3,000,001$ - Rp. $4,000.00$ & 3 & 9,68 \\
\hline & $>$ Rp. $4,000,001$ & 5 & 16,13 \\
\hline \multirow[t]{2}{*}{ Resources } & electronic media & 11 & 35,48 \\
\hline & oral sources & 20 & 64,52 \\
\hline \multirow[t]{4}{*}{ Purpose of visit } & Holiday & 25 & 80,65 \\
\hline & Education / research & 4 & 12,90 \\
\hline & Work & 1 & 3,23 \\
\hline & Others & 1 & 3,23 \\
\hline \multirow[t]{4}{*}{ Frequency of visits } & 1 time & 15 & 48,39 \\
\hline & 2 times & 8 & 25,81 \\
\hline & 3-5 times & 6 & 19,35 \\
\hline & $>5$ times & 2 & 6,45 \\
\hline \multirow{4}{*}{ Visit day } & Weekend & 11 & 35,48 \\
\hline & Working days & 9 & 29,03 \\
\hline & Day off & 10 & 32,26 \\
\hline & Anytime & 1 & 3,23 \\
\hline \multirow{6}{*}{ Time to visit } & Morning & 10 & 32,26 \\
\hline & Noon & 16 & 51,61 \\
\hline & Afternoon & 5 & 16,13 \\
\hline & $<1$ hour & 1 & 3,23 \\
\hline & 12 hours & 11 & 35,48 \\
\hline & $2-5$ hours & 19 & 61,29 \\
\hline
\end{tabular}

Source: Primary Data (2020). 
The majority of respondents who became respondents studied up to a bachelor's degree. The level of education will affect a person's mindset and how to process information. In this case, this includes processing information about the presence of a tourist attraction in an area. Students are the most respondents who visit Boonpring Andeman Tourism Village. This is because of the tourist location which is close to Malang City so that many students make tourist visits. This job will affect the respondent's income, where the income of most respondents is in the range of $\mathrm{Rp} .0-1,000,000$. Most respondents obtained information through oral sources.

Table 3 - Attribute Quadrant Analysis on a Cartesian Diagram using the IPA (Importance Performance Analysis) Method

\begin{tabular}{|c|c|c|c|c|}
\hline Quadrant & Code Attributes & Attributes Name & Mean X & Mean Y \\
\hline \multirow[t]{8}{*}{ A1 } & X.1.1 & Scenery (Attraction) & 3,38 & 4,00 \\
\hline & X.1.5 & Walkway (Attraction) & 3,19 & 4,00 \\
\hline & X.1.8 & Fresh Air (Attraction) & 3,50 & 4,00 \\
\hline & X.2.1 & Entrance (Access) & 3,19 & 3,67 \\
\hline & X.2.3 & Parking area (Access) & 3,50 & 4,00 \\
\hline & X.3.5 & Toilet (Physical Condition of the Facility) & 3,25 & 4,00 \\
\hline & $X .4 .4$ & Worship Place (Cleanliness of Facilities) & 3,25 & 4,00 \\
\hline & $X .5 .4$ & Clean water installation (Supporting Facilities) & 3,38 & 4,00 \\
\hline \multirow[t]{5}{*}{ A2 } & $\mathrm{X} .1 .2$ & Photo spot (Attraction) & 3,31 & 3,33 \\
\hline & $X .3 .10$ & Spot photos (Physical Condition of the Facility) & 3,19 & 3,33 \\
\hline & X.4.1 & Parking area (Cleanliness of Facilities) & 3,19 & 3,33 \\
\hline & X.4.10 & Spot photos (Cleanliness of Facilities) & 3,19 & 3,33 \\
\hline & X.6.1 & Enjoying the scenery and fresh air (Comfort) & 3,50 & 3,67 \\
\hline \multirow[t]{10}{*}{ B } & $\mathrm{X} .1 .7$ & Game rides (Attraction) & 3,38 & 3,00 \\
\hline & X.3.2 & Shops (Physical Condition of Facilities) & 3,31 & 2,67 \\
\hline & X.3.6 & Shelter/cottage (Physical Condition of the Facility) & 3,25 & 2,67 \\
\hline & X.3.8 & Amusement rides (Physical Condition of the Facility) & 3,25 & 3,00 \\
\hline & X.3.9 & Information Center (Physical Condition of Facilities) & 3,31 & 2,00 \\
\hline & X.4.6 & Shelter/cottage (Cleanliness of Facilities) & 3,25 & 2,67 \\
\hline & $X .4 .8$ & Playground (Facilities Cleanliness) & 3,25 & 2,67 \\
\hline & X.4.9 & Information center (Facilities Cleanliness) & 3,19 & 1,67 \\
\hline & X.6.3 & Enjoying selfies (comfort) & 3,31 & 3,00 \\
\hline & X.6.5 & Enjoying games/rides (Comfort) & 3,31 & 2,00 \\
\hline \multirow[t]{2}{*}{ C1 } & $\mathrm{X} .1 .6$ & Shops (Attraction) & 2,94 & 3,00 \\
\hline & $\mathrm{X} .2 .2$ & Public transportation (Access) & 2,31 & 3,00 \\
\hline \multirow[t]{3}{*}{$\mathrm{C} 2$} & X.1.3 & Animals (Attraction) & 3,06 & 2,33 \\
\hline & $X .4 .2$ & Shops (Cleanliness of Facilities) & 3,06 & 3,00 \\
\hline & X.6.4 & Enjoy shopping (Convenience) & 3,06 & 2,00 \\
\hline \multirow[t]{16}{*}{$\mathrm{D}$} & $\mathrm{X} .1 .4$ & Vegetation (Attraction) & 3,13 & 4,00 \\
\hline & X.1.9 & Culinary (Attraction) & 2,81 & 3,67 \\
\hline & X.2.4 & Directions (Access) & 3,06 & 3,33 \\
\hline & X.3.1 & Parking area (Physical Condition of the Facility) & 3,06 & 4,00 \\
\hline & X.3.3 & The place to eat (Physical Condition of the Facility) & 3,00 & 3,67 \\
\hline & X.3.4 & Worship place (Physical Condition of the Facility) & 3,13 & 4,00 \\
\hline & X.3.7 & Trash can (Physical Condition of the Facility) & 3,13 & 3,33 \\
\hline & X.4.3 & The place to eat (Cleanliness of Facilities) & 3,00 & 4,00 \\
\hline & X.4.5 & Toilet (Facility Cleanliness) & 3,13 & 4,00 \\
\hline & X.4.7 & Trash can (Cleanliness of Facilities) & 3,06 & 3,33 \\
\hline & $X .5 .1$ & The communication network (signal) (Supporting Facilities) & 2,94 & 3,67 \\
\hline & $X .5 .2$ & Internet network (Supporting Facilities) & 2,75 & 4,00 \\
\hline & $X .5 .3$ & Electricity network (Supporting Facilities) & 3,06 & 3,33 \\
\hline & $X .5 .5$ & Sewage system (Supporting Facilities) & 2,94 & 4,00 \\
\hline & X.6.2 & Enjoy culinary / food (comfort) & 3,06 & 3,33 \\
\hline & & Average Level of Conformity & 3,15 & 3,33 \\
\hline
\end{tabular}

Source: Primary Data (2020).

Most visitors make tourist visits with the main purpose of being a vacation. The frequency of visits is mostly done once with a choice of time to visit on weekends or holidays. This means that on weekends or holidays, the manager must be able to anticipate large numbers of visits. When the visit is carried out in the afternoon with duration of 2-5 hours 
once a visit. During the visit, visitors spend time enjoying the scenery, fresh air, rides, culinary tours, taking selfies, and shopping for souvenirs in shops at tourist sites.

Furthermore, the calculation of the average level of attribute satisfaction becomes the basis for determining whether the performance of a product attribute is good or not, by comparing the average satisfaction of each attribute (Xi) with the average satisfaction of all attributes (\ overline $(\overline{X i})$. Meanwhile, the average importance level of attributes determines the importance or not of an attribute by comparing the average value of the importance level of each attribute $(\mathrm{Yi})$ with the average importance of all attributes $(\overline{Y i})$. The calculation of the average level of satisfaction and the level of importance of the attributes in Boonpring Andeman Tourism Village can be seen in table 3.

Based on the calculation, it is known that the average value of the satisfaction level of all attributes on the products in Boonpring Andeman Tourism Village is 3.15 . While the average value of the level of importance obtained is 3.33. These values are the basis for determining the good or bad performance of service attributes and the importance of the absence of these service attributes. These values will become the $X$ and $Y$ axes of the Cartesian diagram.

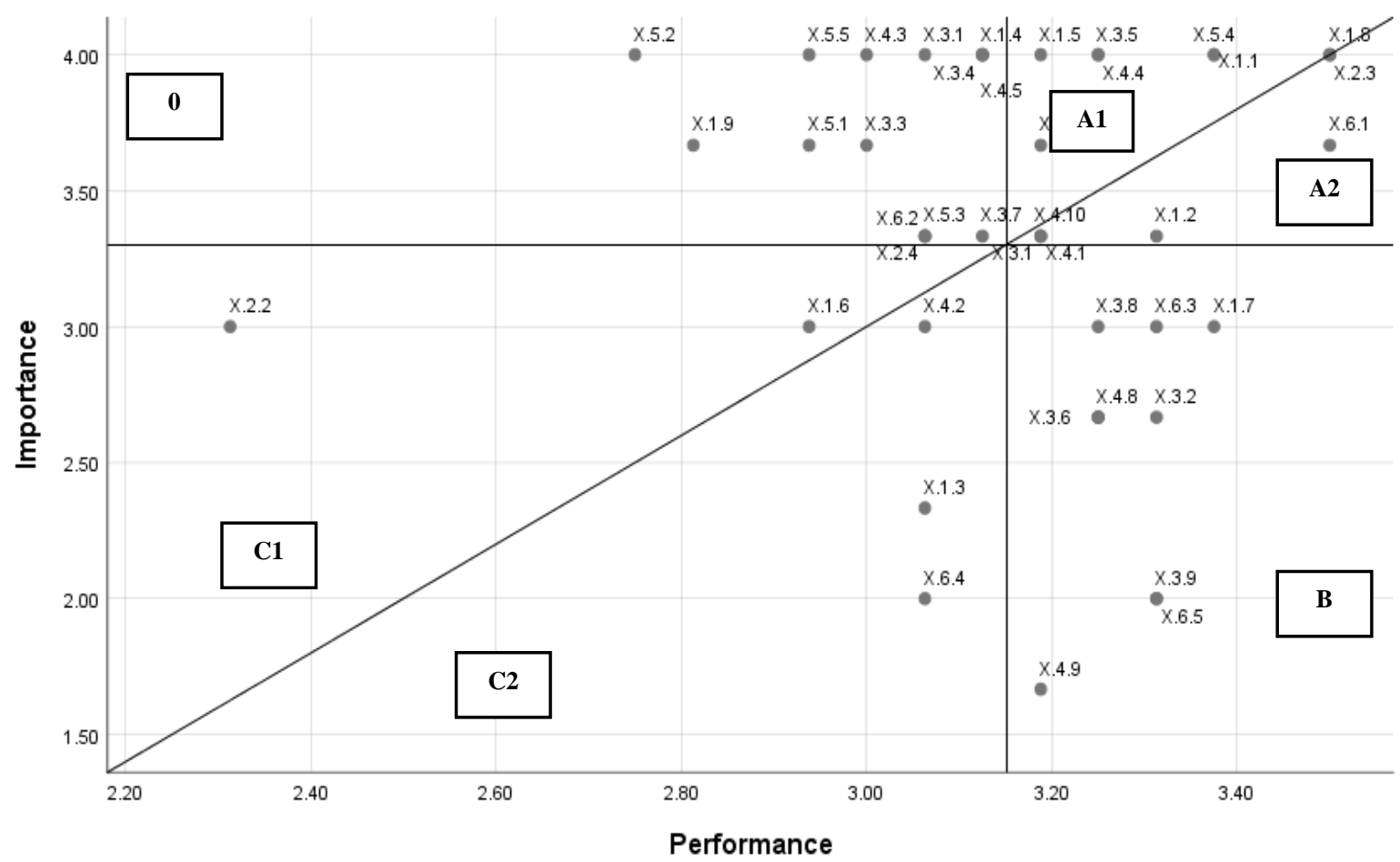

Figure 2 - Cartesian diagram

Cartesian diagram analysis on Importance Performance Analysis (IPA) is done by comparing the level of importance (expectation) with company performance. Analysis using this diagram aims to determine the position of each attribute that affects the level of customer satisfaction based on the quadrant occupied by these attributes. The results of this analysis can help the company allocate its resources to improve the performance of an attribute so that these attributes can provide greater satisfaction with the overall satisfaction level, for example through improving attributes that are considered important, but their performance is still lacking by implementing new marketing strategies. . The results of the analysis using a Cartesian diagram with the Importance Performance Analysis (IPA) method can be seen in Figure 2. diagram.

The following is an interpretation of each quadrant of the attributes in the Cartesian

1. Quadrant A1 (Keep up the good work). Attributes that are in this quadrant mean attributes that are considered important and have good performance and almost meet 
consumer expectations. The attributes in this quadrant are also the main strength that can be used to compete with similar products. The performance of the attributes in this quadrant must be maintained by the tourism management. Some of the attributes included in quadrant A1 are the attractiveness variables (scenery, paths, fresh air), accessibility variables (driveways and parking areas), the physical condition of toilets, cleanliness of the worship place, and clean water installations. The purpose of visitors visiting nature-based tourist objects mostly has the aim of enjoying the natural scenery, cool air, and beautiful atmosphere in the countryside and this is following the expectations of visitors who are visiting Boonpring Andeman Tourism Village.

2. Quadrant A2 (Warning). Attributes that are in this quadrant are attributes that are considered important by consumers and have good performance, but their performance must be maintained and maximized because they significantly affect customer satisfaction. If the attributes in this quadrant experience a decrease in performance, then customer satisfaction can decrease drastically. The attributes that are in quadrant $\mathrm{A} 2$ are from the attractiveness and physical condition of the photo spot, cleanliness of the parking area, and photo spot as well as the comfort of enjoying the view and fresh air.

3. Quadrant B (Concentrate here). Attributes in this quadrant are important attributes that require immediate handling to improve their performance because they are one of the service weaknesses that have a major impact on customer satisfaction. The attributes in quadrant B are attractiveness (rides for games), variable physical conditions of facilities (shelters/huts, amusement rides, information centers), variable cleanliness of facilities (shelters/huts, game rides, information center), and comfort while taking selfies and enjoying. games / rides. Consumers feel that the physical condition and cleanliness of the shelter or cottage are not following their wishes, as well as comfort in taking selfies. The management of Boonpring Andeman Tourism Village must be able to meet consumer desires for this attribute because it has a very significant effect on the level of consumer satisfaction, considering that shelters or cottages are something that consumers need while in tourist locations to take a short break.

4. Quadrant C1 (Low priority). Attributes that are in this quadrant mean attributes that are considered less prioritized for treatment, because they are minor weaknesses in the product. The attributes that are in quadrant $\mathrm{C} 1$ include the attributes of shop attractiveness and accessibility of public transportation. This attribute is considered insignificant and has low performance, so there is no need for excessive handling because it does not have a significant impact on the level of customer satisfaction. Boonrping Andeman Tourism Village is a nature-based tourism, where visitors come with the main aim of enjoying the natural beauty and fresh air, so that the attributes of animal attraction and shopping attraction are not considered important by visitors. Apart from that, the accessibility of public transportation is also considered insignificant because the average visitor comes to Boonpring Tourism Village using a private vehicle.

5. Quadrant C2 (Improve). Attributes that are in the C 2 quadrant are attributes that need to be improved at a certain time to encourage the level of consumer satisfaction with the product, because the attributes in this quadrant are close to the B quadrant which means they can be important at certain times. The attributes included in the C2 quadrant are attributes of animal attractiveness, cleanliness of shops, and comfort while enjoying shopping. This attribute has a low level of performance and is not considered important by consumers. However, this attribute can be improved at any time to encourage the level of customer satisfaction in the future.

6. Quadrant $D$ (Possible overkill / Leave). The attributes that are included in quadrant $D$ include attractiveness variables (vegetation, culinary), accessibility variables (road signposts), the variable physical condition of the facility (parking area, dining area, prayer room, and trash can), variable cleanliness of facilities (places to eat, toilets, and trash cans), variable supporting facilities (electricity network signal) and comfort 
attributes while enjoying culinary delights) The attributes in this quadrant indicate that the resources owned by the company are too allocated to these attributes and need to be distributed to help other attributes. For example, the manager can allocate resources for the physical conditions and cleanliness of the place to eat, prayer room, and trash can to attributes that are in Quaternary B that have poor performance, such as the physical condition and cleanliness of the shelters, game resistance, and information center. The manager can also distribute resources for culinary handling to handling selfie spots and rides.

The overall level of customer satisfaction is analyzed using the Customer Satisfaction Index (CSI) method. This method considers the level of importance and level of performance/satisfaction of service quality attributes used in the study. Aritonang (2005) explains that the value in the Customer Satisfaction Index (CSI) is directly proportional to the average value of importance and the average value of the attribute performance. Because it is directly proportional, increasing the average value of importance and satisfaction will increase the CSI value. The following is the result of calculating the CSI value presented in Table 3.

Based on the calculation of the Customer Satisfaction Index (CSI) value in table 3 above, it is known that the CSI value obtained is $75.21 \%$. This CSI value is in the range of 0.66 - 0.80, which means that the consumer satisfaction index at Boonpring Andeman Tourism Village is in the "satisfied" category. Even though the calculation results show the "satisfied" category, the manager must still maintain the performance of several attributes and improve them. This is done to maximize service quality and maximize overall customer satisfaction levels.

Table 3 - Calculation of Customer Satisfaction Index (CSI) Score

\begin{tabular}{llllll}
\hline No & Variable & MIS & WF & MSS & WS \\
\hline 1 & Attractiveness & 3.48 & 11.11 & 3.18 & 35.53 \\
2 & Accessibility & 3.50 & 25.00 & 3.02 & 76.49 \\
3 & Physical Condition of the Facility & 3.27 & 10.00 & 3.19 & 31.74 \\
4 & Cleanliness of Facilities & 3.20 & 10.00 & 3.16 & 31.50 \\
5 & Supporting Facilities Condition & 3.80 & 20.00 & 3.01 & 60.24 \\
6 & Comfort & 2.80 & 20.00 & 3.25 & 65.33 \\
\hline Weight Total (WT) & & & & 300,83 \\
\hline CSI $=($ WT/4) $\times 100 \%$ & & & & 75.21 \\
\hline
\end{tabular}

Source: Primary Data (2020).

The attributes with a low WS score include the physical condition and cleanliness of the facility. In the physical condition variable, the lowest attribute value is the physical condition of the facility. In the results of the IPA analysis, the physical condition of the shops is included in quadrant $B$ (concéntrate here), which means that the management of Boonpring Andeman Tourism Village must overcome this as soon as possible because it is a weakness and has an impact on the level of consumer satisfaction. In line with the low WS value for the physical condition attribute of shops, the cleanliness attribute of information facilities also scores the lowest and is in the B quadrant. This means that the tourism management must deal with this problem. Based on the IPA analysis, the manager can handle it by reallocating some of the resources used to handle the physical conditions and cleanliness of eating places, prayer rooms, and trash cans to handling the physical conditions of shops and the cleanliness of information facilities.

\section{CONCLUSION}

The CSI score of Boonpring Andeman Tourism Village which has not reached $100 \%$ indicates that there is still room for improvement to achieve better visitor satisfaction, for example by maintaining attribute performance in quadrant $A 1$ and improving attribute performance in quadrant $B$ which is a priority for performance improvement. by allocating a portion of the resources from the $D$ quadrant. 
Based on the results of the discussion, the attributes that are considered important and have good performance by visitors are the view, paths, fresh air, access to the driveway and parking area, the physical condition of the toilets, cleanliness of the worship place and clean water installations. Possible to improve the performance is a game vehicle; physical condition and cleanliness of shelters / cottages, amusement rides, information centers; and comfort when taking selfies and enjoying games / rides. Performance improvement for attributes that need to be handled immediately so that visitor satisfaction can be increased can be done by reallocating excess resources for handling an attribute to other attributes that are not performing well. For example, the manager can allocate resources used to deal with the physical conditions and cleanliness of places to eat, prayer rooms, and trash cans for handling the physical conditions of shops and the cleanliness of information facilities. This is because if it is not handled immediately, it will have an impact on decreasing customer satisfaction.

\section{REFERENCES}

1. Aritonang, L.R. 2005. Kepuasan Pelanggan. PT Gramedia Pustaka Utama.

2. Biesok, G. \& J. Wyród-Wróbel. 2015. Decision Making on Various Approaches to Importance-Performance Analysis (IPA). European Journal of Business Science and Technology. 3(1): $123-131$.

3. BPS. 2019. Survei Industri Pariwisata untuk Penyusunan Database. www.bps.go.id.

4. Chen, J., S.W. Stanis., C. Barbieri., X. Shuangyu. 2010. An Application of ImportancePerformance Analysis to Recreational Storm Chasing. Proceedings of the 2010 Northeastern Recreation Research Symposium. 45-51.

5. DPMD Jatim. 2020. BUMDesa Berdasarkan Unit Usaha. www.datadesacenter.dpmd.jatimprov.go.id.

6. Sarjono, B. (2013). Pengelolaan Strategi dalam Persaingan Bisnis. Jurnal Manajemen Strategi. 9 (1): $58-61$.

7. Syafi'i, M \& D. Suwandono. 2015. Perencanaan Desa Wisata Dengan Pendekatan Konsep Community Based Tourism (CBT) di Desa Bedono, Kecamatan Sayung, Kabupaten Demak. Jurnal Ruang. 1 (2): 51-60. 